- An outline of Anglo-Saxon remedies for dental problems.

- A description of an Anglo-Saxon operation for a cleft palate.

- Archaeological evidence for an Anglo-Saxon dentist or 'tooth drawer'.

\title{
Dental treatment in Anglo-Saxon England
}

\author{
T. Anderson ${ }^{1}$
}

Anglo-Saxon medical literature suggests that care of the teeth was largely limited to non-invasive treatment. Cures, mainly for
toothache, were based on herbal remedies, charms and amulets. Herbal potions also treated oral problems as diverse as caries
and facial deformities. However, surgical intervention for cleft lip is mentioned in the later documents. Skeletal evidence
confirms that cleft lip and palate was definitely known to the Anglo-Saxons. A possible dentist's grave has been identified.

\section{INTRODUCTION}

During the Anglo-Saxon period, from the early fifth century AD to the Norman Conquest (1066AD), many diseases were caused by extrinsic factors. Sharp localised pains in man and beast were related to mischievous elves shooting darts, so-called elfshot. ${ }^{1}$ Worms, serpents and flying insects were also considered to be a source of danger, as they could spread poison. ${ }^{1}$ Documentary sources indicate that toothache was a frequent problem. Most cures were based on herbal remedies, charms and amulets. Documentary sources provide only limited evidence for surgery. However, an operation for cleft lip is known from late Anglo-Saxon sources and two child skeletons display cleft palate.

\section{DOCUMENTARY EVIDENCE}

\section{The Leechbooks of Bald}

These books, possibly compiled in the ninth century, were copied down in Old English at Winchester in the middle of the tenth century. This makes it the oldest extant vernacular medical work. ${ }^{1}$ The MS (Royal 12.d, xvii) is housed at the British Library. ${ }^{1}$ The third section, with more magical remedies and charms, most accurately reflects English medical practice of the time, whereas volumes I and II contain more mediterranean

\footnotetext{
1*Osteo-archaeologist, Vichy House, 15 St Mary's Street, Canterbury, Kent CT1 20L

${ }^{*}$ Correspondence to: Trevor Anderson

Email:anderson.trevor@tiscali.co.uk
}

\section{Refereed Paper}

Received 24.06.03; Accepted 23.10.03

doi: 10.1038/sj.bdj.4811623

๑ British Dental Journal 2004; 197: 273-274 influence. ${ }^{1-2}$ Book III contains several vernacular remedies for oral problems:

For toothache:

'...chew pepper often with the teeth, it will soon be better for him. Again boil henbane's root (Hyoscyamus niger) in strong vinegar or in wine, set it on the sore tooth, and let him chew it with the sore tooth sometimes; he will be hale' [p.385 4] ${ }^{1}$

A recipe 'For a mouth broken inside':

'take a plum (Prunus domestica) tree's leaf, boil it in wine, let him swill his mouth with it' [p.385 5] ${ }^{1}$

Apparently an attempt to combat advanced infection, probably associated with advanced periodontal disease.

A remedy against 'hollow teeth' apparently refers to large carious cavities:

'...chew bothen's [? Rosmarinus officinalis] root with vinegar on that side' [p.385 4] ${ }^{1}$

A complicated remedy, including phlebotomy, is known for a "crooked or deficient' mouth. This may refer to a cleft lip or palate:

'...take coriander (Coriandrum sativum), dry it out, make it into dust, mix the dust with the milk of a woman who is feeding a boy-child, wring it out through a blue cloth and smear the healthy cheek with it, and drip it into the ear carefully. Make a bathing, then: take bramble (Rubus fruticosus.) bark and elm (Ulmus campestris) bark, ash (Frax- inus excelsior) bark, blackthorn (Prunus spinosus) bark, apple tree (Pyrus malus) bark, ivy (Hedera helix) bark - the lower parts of all of these - and cucumber, smearwort (Aristolochia rotunda), boarfern (Polypodium vulgare), elecampane (Inula helenium), elfthon (Circaea lutetiana), betony (Stachys betonica), horehound (Marrubium vulgare), radish (Raphanus sativus), agrimo$n y$ (Potentilla anserina), scrape the plant into a cauldron and boil them thoroughly. Once it is thoroughly boiled, take it off the fire and let it stand and make the man a seat over the cauldron and cover the man so that the vapour cannot get out anywhere except that he might breathe it in. Bathe him with this bathing for as long as he can bear it. Have another bathe ready for him then, take an entire anthill - of those that sometimes fly, it will be red - boil it in water, bathe him with it, with excessive heat. Then make him a salve: take some plants of each of those kinds, boil in butter, smear the sore parts with it, they will soon come back to life. Make him a lye from elder (Sambucus niger) ashes, wash his head with it cold, it will soon be better for him; and let the man's blood each month on a five-night-old moon, and on a fifteen, and on a twenty' [p.399 47] ${ }^{1}$

\section{Herbarium of Pseudo-Apuleius}

This collection of treatments was translated from the Latin into Old English in the ninth or tenth century. ${ }^{2}$ Four copies of the translated text exist (British Library: Harley 585, 6258B; Cotton Vitellius C.iii; Bodleian Library: Hatton 76) which suggests that these non-native remedies were popular in late Anglo-Saxon and early medieval England. ${ }^{2}$ The earliest MS (Harley 585), written 
c.1000AD, also contains the Lacnunga (see below). Only the Cotton MS is illustrated, with mediterranean plants, unfortunately the green pigment has caused damage to the vellum. ${ }^{2}$ The fact that the scribes re-arranged sections of the text argues that they were being copied and translated for use rather than simply exercises in penmanship. $^{2}$

There are several remedies that refer to toothache:

'take...betonica (Stachys betonica), and boil in old wine or vinegar to a third, it heals wonderfully pain and swelling of the teeth' [p.283 1.8 $]^{1}$

Take ball thistle (Carduus sp.) seeds, 'pounded, give it to drink in water, it helps' [p.361 153.3. ${ }^{1}$

give them to eat rosemary (Rosmarinus officinalis) roots, 'without delay it will take away the pain of the teeth, and let him hold the juice in his mouth, it will soon heal the teeth' $[\mathrm{p} .32581 .1]^{1}$

take yarrow (Achilea millefolium) roots, 'give it to eat fasting' [p.329 90.2] ${ }^{1}$

Take henbane root (Hyoscyamus niger), 'boil in strong wine, let him sip it thus warm and let him take hold of it in his mouth, soon it will heal the pain of the teeth' [p.291 5.3 $]^{1}$

:.give flowers of the nightshade (Solanum nigrum) to eat' $\left[\right.$ p.323 76.3 ${ }^{1}$

Cornflower (Centaurea sp.) and spearmint (Mentha sp.) were considered useful against both toothache and loose teeth:

Cornflower 'helps with a wonderful power; its sap and its powder is to be kept in winter because at certain times it does not show; you must keep its sap in a rams' horn, also dry out the powder and keep it; truly also it takes effect potently to the same use when drunk with wine' [p.303 $30.3]^{1}$

Spearmint 'give it to eat fasting, it strengthens the teeth' $\left[\right.$ p.333 97.2 ${ }^{1}$

Against 'canker of the teeth' from which 'too often the teeth fall out':

'bonewort (Symphtum officinale) leaves pounded with honey' [pp.365-366 165.3 $]^{1}$

For pain in the gums:

if one carries clover (Trifolium sp.) root on his neck, 'his gums will never hurt him' [p.319 70.1 $]^{1}$
For 'foulness and rottenness of the mouth and gums', apparently galloping pyorrhoea:

take gorse (Ulex sp.), 'boil it, pound with honey, it heals the mouth and gums' [p.355 $[142.2]^{1}$

\section{Lacnunga}

The earliest extant MS of this jumbled collection of folk medicine dates to c. 1000AD and is housed at the British library (MS Harley 585). ${ }^{2}$ It is mainly written in Old English. ${ }^{1}$ Two hands can be recognised, the second, who wrote the final third was even more careless in his copying than the first and included a larger proportion of Latin items. ${ }^{2}$ One charm for toothache contains a garbled incomprehensible charm, based on Latin. The charm had to be sung at sunset and name the sufferer and his father. Interestingly, it makes a reference to the pain being caused by a worm [p.191 22]. ${ }^{1}$ A view that became widespread in the medieval period. ${ }^{3}$ The idea that a worm was responsible for dental disease was first mentioned in Babylonian medicine. ${ }^{4}$ The 'tooth worm' was also discussed by Roman authorities, including Pliny and Dioscorides. $^{5}$

\section{SURGICAL EVIDENCE}

Surgical intervention is rarely mentioned in the texts, there is a reference to an operation for harelip in Bald's Leechbook, which includes curettage and suturing:

...pound mastic very fine, add white of an egg and mix as you do vermilion, cut with a knife, sew securely with silk, then anoint with the salve outside and inside before the ilk rot. If it pulls together, arrange it with the hand, anoint again immediately' [p. 169] ${ }^{2}$

\section{ARCHAEOLOGICAL EVIDENCE}

Skeletal evidence provides information on the prevalence of dental disease including ante-mortem tooth loss; caries experience; calculus deposition and enamel hypoplasia as well as malocclusion. Two examples of cleft palate have been identified; both individuals failed to reach adulthood. ${ }^{6-7}$ however, definite evidence for dental treatment or deliberate extraction of teeth is limited. One pagan Anglo-Saxon female from Deal may have had an infected upper first molar rather clumsily extracted. ${ }^{8}$

Two adult males, dated to the Christian Anglo-Saxon period, from Dunstable were buried with a pouch or bag around the neck containing human teeth. ${ }^{9}$ The date argues against a pagan ritual; also an amulet would probably consist of a single animal tooth, possibly pierced to wear on a necklace. ${ }^{1}$ Another possibility is that they were itinerant tooth-drawers, or dentists, that kept examples of successfully extracted teeth to prove their ability to prospective patients.

\section{CONCLUSION}

The majority of the remedies are against toothache. Several appear to be of limited value. However, nightshade (Solanum niger) and henbane (Hyoscyamus niger), the latter mentioned in both Bald's Leechbook and the Herbarium, do have narcotic and inebriating powers. Henbane was certainly used for the relief of dental pain in the Roman period. ${ }^{5}$ To the Anglo-Saxon mind, it is possible that henbane was used since it bears a superficial resemblance to a tooth. ${ }^{1}$ The Herbarium does mention that the ball thistle was beneficial against both toothache and snakebites, ${ }^{1}$ a possible correlation between toothache and flying venom. The Lacnunga makes reference to dental pain being caused by a worm. This is a view that was first mooted in the Babylonian period and was known to the Romans.

Only the Leechbook of Bald mentions the problem of advanced caries destruction, socalled 'hollow teeth'. The same text refers to both herbal remedies and surgery as a cure for cleft-lip. Based on skeletal material, two cases of cleft palate are known, neither individual reached adulthood. There are cures for 'loose teeth' and 'canker of the teeth'; the latter often causes teeth to fall out. However, there is limited evidence for deliberate extraction. It is possible that two males, each buried with a pouch containing human teeth, may have been dentists, who kept examples of successfully extracted teeth.

1. Pollington S. Leechcraft Early English Charms Plantlore and Healing. pp71, 72, 74, 130, 191, 283, $291,303,319,323,325,329,333,355,361,365,366$ 385, 399, 456-458, 461-464. Hockwold-cum-Wilton: Anglo-Saxon Books, 2000.

2. Cameron, M L. Anglo-Saxon Medicine. pp32, 34-47, 59-64. Cambridge: Cambridge University Press. Cambridge Studies in Anglo-Saxon England 7, 1993.

3. Getz F M. (ed) Healing and Society in Medieval England A Middle English. pp 92-94. Madison: Wisconsin University Press, 1991

4. Garrison F H. An Introduction to the History of Medicine. 4th ed. p 64. Philadelphia: W B Saunders Company, 1929.

5. Jackson R. Doctors and Diseases in the Roman Empire. p121. London: British Museum Press, 1988

6. Boddington A. Raunds Furnells The Anglo-Saxon Church and Churchyard. p 123. London: English Heritage Archaeological Report No 7, 1996.

7. Brothwell D R. Digging up Bones. 2nd ed. Plate 17B. London: British Museum, 1972.

8. Anderson T, Andrews J. The human skeletons. In: Parfitt K, Brugmann B. The Anglo-Saxon Cemetery on Mill Hill, Deal Kent. pp 214-239. London: The Society for Medieval Archaeology Monograph Series No. 14, 1997.

9. Matthews $C L$. The Anglo-Saxon cemetery at Marina Drive, Dunstable. Beds Arch J 1962; 1: 25-47. 